\title{
O PARANÁ NO DISCURSO LITERÁRIO
}

Marilene Weinhardt ${ }^{*}$

\section{A}

independência do estético em relação ao real não importa necessariamente em fuga ou negação do externo. Frequientemer:te o artista trabalha com os elementos do mundo que o rodeial , :ererenciais geográficos e temporais que podem coincidir ou não com os referenciais do consumidor do objeto estético. Mesmo quando há coincidência, o leitorespectador-ouvinte desvia o olhar da realidade originária, para se deixar seduzir pela nova forma gerada pelo filtro da percepção do outro. Produtor e consumidor da arte resultante desse modo de relacionamento com a sociedade podem ser movidos pela mesma necessidade: a busca identitária. Nossos contornos se delineiam, ainda que precariamente, no instante em que nos reconhecemos diferentes, singulares. As figurações do espaço físico e social em que se vive, ou em que viveram os antepassados, é um dos modos de se surpreender essa fisionomia, nas suas aceitações e nas suas recusas, nas idealizações e nos confrontos.

A existência política do Paraná é posterior ao delineamento de suas especificidades, ainda que o desmembramento não tenha acontecido por imposições culturais da população. A necessidade de ser paranaense, no sentido de ter uma cultura diferenciada e reconhecida como tal, não se apresentou no momento da emancipação, assim como não se mostrou como uma urgência no quadro de definição da nacionalidade que presidiu o espírito romântico nas

* Universidade Federal do Paraná 
províncias já estabilizadas. Delegamos então a representação de nossa imagem ora aos vizinhos meridionais, ora aos setentrionais. As primeiras comunidades do litoral e do planalto têm origens bastante antigas, mas Paraná é um nome e um conceito que contam poucas décadas mais de um século. É tempo exíguo para se construir uma identidade. Na crônica de viagem Passeio à minha terra, publicada em 1860, Salvador José Correia Coelho, natural do Príncipe (hoje Lapa) e que exercia a magistratura no estado de São Paulo, relata a visita que fizera em 1844 à região de origem, quando estudante de Direito na terra dos bandeirantes. $\mathrm{O}$ autor demonstra verdadeira ojeriza pelo nome dado à jovem província. Chegando à altura do relato em que alcança Curitiba, Correia Coelho diz da antiga condição de "cabeça de comarca" da cidade, para prestar informações de ordem legal sobre a elevação à categoria de província, fato que teve lugar entre o tempo da viagem e o da escrita, lamentando:

Não vejo razão na alteração que a lei trouxe, baptizando a provincia com o nome de Paraná.

Seria a existencia do rio - "Paraná" - que banha-lhe a parte occidental? mas essa corrente fluvial não pertence privativamente ao imperio; ha naçōes ribeirinhas á sua margem direita e esquerda que tem sobre ella iguaes direitos.

Seria porque nessa epocha, infeliz para o imperio, havia um estadista caprichoso do mesmo nome que influia nas deliberaçōes legislativas e politicas? - seja como fôr, a denominação foi desgraçada, má e frivola.

Se cumpria dar um nome de rio á nova provincia, porque não provincia do - "Iguassú"? - mas antes, porque não provincia de - "Coritiba" -? que necessidade de confundir essa denominação com a de Paraná, cidade capital da Confederação argentina? -É de lamentar que a individualidade arbitraria imponha os seus caprichos despoticos á um povo culto, condescedente ao ponto d'acceitar as veleidades de quem se julga na esphera dos conhecimentos humanos um novo Salomão!

As críticas são dirigidas a escolhas políticas e se fazem da perspectiva da data de publicação, mas o olhar que o viajante recaptura pela palavra é anterior à emancipação. Filho pródigo que retorna à casa paterna, ele não se furta ao

I COELHO, Salvador José Correia. Passeio à mimha terra. São Paulo: Typografia da Lei, 1860. p. 52-53. Ediçāo em fac-símile, 1968. 
elogio das excelências do clima, da beleza da paisagem, da gentileza dos habitantes, contemplando não só o destino final da viagem, mas também os lugares por onde passa. O discurso transita entre o tom informativo característico da literatura de viagens e o lirismo da saudade de quem revê "o lugar, em que descerrára os olhos á luz do dia". ${ }^{2}$ A intimidade do escritor com o espaço descrito é uma novidade nessa tradição originada do relato de viajantes estrangeiros, prenunciando virtudes que só se realizarão plenamente na literatura brasileira nas melhores expressões regionalistas.

O texto de Salvador José Correia Coelho antecede a Revolução Federalista em três décadas e a viagem relatada ocorreu exatos 50 anos antes, a despeito de haver uma espécie de convenção não escrita que determina ao país que se aperceba da existência do Paraná a partir daquele acontecimento histórico. Uma das funções que a crônica do bacharel cumpre é chamar a atenção para a pobreza de registros, no discurso literário, sobre o Paraná anterior às últimas décadas do século XIX, virtude talvez maior que a da própria representação que realiza.

O tempo da Revolução Federalista é o focalizado por Tasso da Silveira no romance Sombras no caos, de 1958. Não são os acontecimentos bélicos que ocupam o narrador. O par amoroso também é circunstancial. O grande tema é a população de Curitiba, ou melhor, uma fatia dela, na última década do século passado, sobretudo personagens designados como operários, ainda que pequenos proprietários, muitos descendentes de imigrantes alemães, mas que não experimentaram choque cultural ou dificuldades de integração decorrentes da origem adventícia. Leitor de Marx, um desses proprietários-operários intentava implantar o projeto socialista na "Associação Proletária Paranaense", entidade cultural da época que, ao lado do "Grêmio Dramático Artur Bernardes", é colocada em destaque pelo narrador.

A atenção à narrativa do poeta paranaense que, no Rio de Janeiro, integrou o grupo Festa deve-se ao esforço de construir o romance de costumes da Curitiba finissecular, ainda que, décadas depois da renovação modernista e dos caminhos seguros da ficção de 30 , seja vazada em moldes convencionais, registrando características geográficas e climáticas da urbe, onde personagens ensimesmados deambulam sob frio intenso, velhos estereótipos da cidade e de seus habitantes.

Real ou imaginário, o frio é um dos grandes fantasmas a assombrar curitibanos. No primeiro número de Pallium, "Revista de Arte", veículo tão a gosto do Simbolismo, momento literário com intensa produção em Curitiba mas predominantemente com temática distanciada do cotidiano, como convém a essa

2 COELHO, op. cit., p. 55 
estética, Nestor de Castro publicou o texto "Inverno". A vivência dos rigores do frio toma uma forma exacerbada que se delineia desde o primeiro parágrafo: "Inverno! Inverno! duro espiculo alfịnetante dos gêlos; atroz phantasma nebuloso da humida Siberia triste, que vens rolando ás fortes enchurradas polares das luas-novas de Junho, eu sinto a tua epinescente algidez de morte, como se fôra a sangradora unha torsa de um urso branco da Groelandia, ferir as phantasias bizarras do meu Sonho!...."3

A nova convulsão social que atinge o Estado do Paraná e o Estado de Santa Catarina, poucos anos depois da luta armada entre pica-paus e maragatos, é campo fértil para a ficção. Os catarinenses foram parceiros na luta e na exploração da temática. Não são poucos os textos ficcionais de escritores do vizinho estado do sul que situam a ação nesse período, ou ao menos lhe fazem referência. Pelo nome que a história institucionalizada lhes emprestou, os episódios ficam restritos a sua face político-administrativa, no título Guerra do Contestado, reconhecendo-se apenas a questão de limites estaduais, enquanto os componentes de luta camponesa e de messianismo ficam na sombra. O Sul também teve o seu Antônio Conselheiro, como teve o seu Canudos. Casa verde (1963), do paranaense Noel Nascimento, destaca a importância da figura do líder messiânico, posição ocupada, na revolta popular, pelos "monges" João Maria e José Maria. Como a conflagração ocorreu numa região que ora pertencia ao Paraná, ora a Santa Catarina, por decisões que não atendiam a especificidades culturais da população, mas a interesses políticos, mesmo porque não existiam diferenças culturais, interessa a caracterização do espaço e do modo de vida, independentemente de acordos entre governantes haverem determinado posteriormente sob a jurisdição de que unidade da federação ficaria esta ou aquela porção. É à figuração do homem, do habitante da região, sobretudo no seu aspecto psicossocial, que Noel Nascimento dedica o melhor de sua capacidade inventiva. Suas personagens agem e pensam como os hábitos e o meio social e geográfico os modelaram. Assim, o espaço rural domina - campos de criação de gado, serras, pequenas áreas de cultivo, serrarias, povoados e, sobretudo, mata nativa, a "casa verde" do título. O espaço urbano também marca presença. Suas vozes aparecem na forma de registro escrito, forma culta por excelência, explorando a contraposição: todo um capítulo é constituído da colagem dos necrológios registrados pela imprensa, em homenagem ao comandante João Gualberto, morto em campanha, logo no início da luta armada.

3 CASTRO, Nestor de. Inverno. Pallium. Curitiba, n. 1, p. 6, set. 1898. Ediçāo fac-similar, Curitiba: Secretaria de Estado da Cultura e do Esporte, 1982. 
Épocas de lutas, propiciando o clima de exacerbação próprio para a dramaticidade, constituem o pano de fundo por excelência para a narrativa, histórica ou não, inscrever heróis e vilōes. Mas nem todos olham o mundo pelo óculo trágico. Emílio de Menezes prefere espiar as manobras palacianas e os políticos no poder pela lente da irreverência, desmascarando a seriedade suspeita que paira sobre as atitudes de homens públicos. Assim, Francisco Xavier da Silva, presidente do estado por três legislaturas - 1892, 1900 e 1908 - portanto diretamente envolvido na política estadual durante a Revolução Federalista, quando o vice-presidente Vicente Machado assumiu o poder, e no período em que se criaram ou se acirraram as condições que culminaram na luta armada dos camponeses, comparece numa voz paródica em primeira pesson, num soneto parnasiano em que os versos decassílabos estilizam o discurso oficial e, concomitantemente, incorporam o tom jocoso com que o discurso popular demonstra sua visada crítica sobre o poder, expressa particularmente nas alcunhas e no traço caricatural:

\section{PANTEÃO DOS SATRAPINHAS}

Curitiba - Um de março - Nota urgente.

Panteão dos Satrapinhas. Eu proíbo

Esse deboche tão irreverente,

De me chamarem lá, chefe da tribo.

Cá por mim eu nem era presidente; Mas o Vicente segurou no estribo.

Eritāo montei, mas não estou contente.

E entrego esta quitanda sem recibo.

Não gosto dessa história de retrato,

Este pensar, já sabem, vem de longe,

Sou inimigo de todo o espalhafato.

Quero ao Bormann passar, que é o nosso Cronge, As rédeas do governo, e desbarato.

- Doutor Xavier da Silva, vulgo Monge. ${ }^{4}$

4 MENEZES, Emílio de. Obra reunida. Rio de Janeiro: J. Olympio/Curitiba: Secretaria da Cultura e do Esporte do Estado do Paraná, 1980. p. 113. 
A Curitiba da segunda década do século recebe uma figuração marcada pela ousadia, numa obra que mescla requinte formal a recursos buscados em outros meios de comunicação. A novela $O$ mez da grippe (1981), de Valêncio Xavier, que instaura o ambiente da época desde o arcaísmo da grafia do título, é um texto produzido pela colagem de diversos discursos cuja contraposição produz o sentido do novo texto. Esse sentido é o caos que a gripe espanhola provoca na pacata província, no último trimestre do ano de 1918. A seleção e a contraposição de colagens - trechos variados de jornais, documentos, depoimentos, anúncios publicitários, versos eróticos, cartões postais - denunciam a devastação provocada pela epidemia e as contradições do poder oficial, que em princípio tenta minorar as dimensões do mal, temeroso de perder o controle, até que a realidade impõe-se com violência, exigindo atuação profilática, que por sua vez também dá oportunidade a arbitrariedades e truculência.

Apesar do pânico reinante na cidade, o mundo continuava a girar, outras urgências requeriam atenção. A 1. ${ }^{a}$ Guerra Mundial conflagrava a Europa e repercutia em Curitiba, com sua populosa colônia alemã, que se defrontava e era afrontada pelo conjunto da população. Os crimes, os encontros sociais, as atividades culturais, os pedidos de ordens diversas, enfim, essa matéria que todos os dias preenche os espaços dos jornais, múltiplas facetas que constituem cada momento, não escapam à tesoura de corte preciso, produzindo um discurso que, oscilando entre o trágico e o humor negro, evidencia a variedade e as contradições do cotidiano, ao mesmo tempo que questiona o discurso histórico tradicional.

Os paranaenses do início do século não tiveram olhos e ouvidos só para guerras, ações governamentais e tragédias. O lirismo também teve a sua hora e vez, expresso de forma em perfeita consonância com a vanguarda artística do país naquele momento. O poema de Brasil Pinheiro Machado publicado na Revista da Antropofagia, "Paizagem de minha terra", não tem ecos de ufanismo ou exotismo românticos, de formalismo parnasiano ou de brumas e distanciamento simbolistas. É uma paisagem vista sem idealizações e sem culpa, décor significando à medida que se integra com seres humanos:

Manhã de domingo de sol reto.

A grande igreja sem estilo

Decorada por dentro por um batismo de Cristo

Feito por um pintor ingenuo

Que quiz ser classico e foi primitivista.

Missa internacional

Com gentes de todas as raças

Ouvindo o padre alemão rezar em latim. 
Agente nem tem vontade de olhar o crucifixo dezolado Nem de rezar

Porque tem lá dentro tanta menina bonita

Que não reza tambem

E fica sapeando agente com meiguice...

Só os polacos de camiza nova por ser domingo

Que vieram com as familias de carroça lá das colonias

Rezam fervorozamente

Enquanto nos seus quintaes

Os chupins malvados e alegres

Comem todo o centeio

Cantando glorias pro sol de domingo.

(PONTA GROSSA) ${ }^{5}$

A concisão do primeiro verso dá o plano maior. Identificados momento e condições, o olhar só poderia convergir para a igreja, vista na sua nudez, sem mascarar as despretensões arquitetônicas, mas desmascarando o artista provinciano. A solenidade do adjetivo internacional é esvaziada pela indicação das dimensões do meio social - terra de imigrantes, que não conta nem com padre nacional, o que não faz muita diferença, porque também a religião é não apenas importada, mas anacrônica e distanciada. A beleza das moças chama a atenção do jovem poeta, como de tantos outros em qualquer tempo, latitude e credo estético, fascínio que não precisa ser expresso por custosos torneios vocabulares. A expressão menina bonita, em sua singeleza, associada ao verbo sapear, também buscado na oralidade, valida o potencial poético do discurso popular. Terra em que o urbano e o rural não têm fronteiras marcadas, com larga margem de convivência, o espaço campesino está representado nos "polacos [...] das colonias", cujo fervor religioso não lhes assegura boa colheita. O deus que seus predadores glorificam é outro.

É também a periferia agricultora ocupando os espaços do centro da cidade uma das marcas da recordação de Helena Kolody sobre a Curitiba de sua infância e adolescência. Ao ser questionada sobre a experiência de morar "na Itupava, naquela época, cheia de lama, indo a pé para a escola", a poeta opta por responder com um poema:

5 PINHEIRO MACHADO, Brasil. Paizagem de minha terra. Revisfa da Antropofagia. São Paulo, ano I, n. 7, p. 6, nov. 1928. Edição fac-similar, São Paulo: Metal Leve, 1975. 


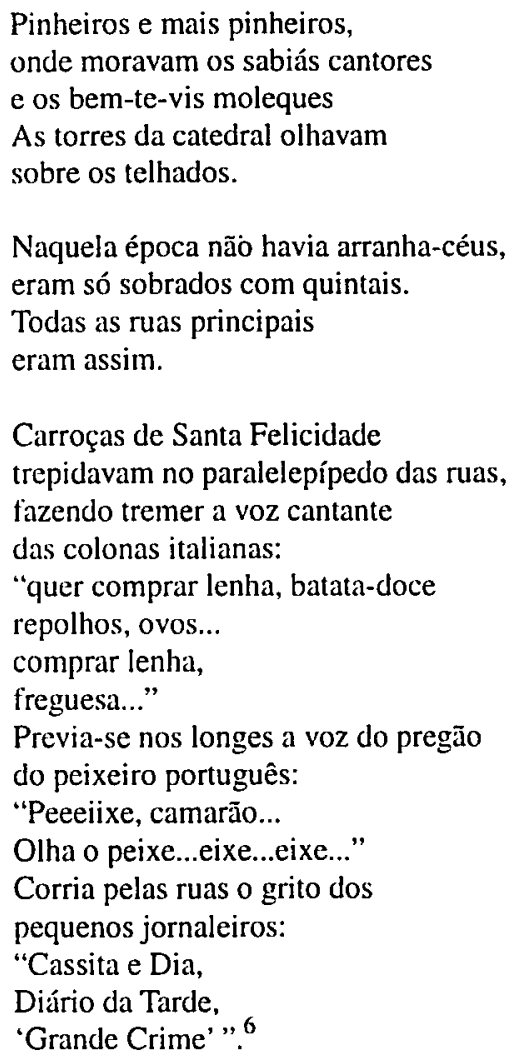

A partir da pergunta cujo centramento residia numa sensação tátil, versando a respeito de uma vivência que deve ter tido sua significativa dose de dificuldade, a poeta migra para o mundo das sensações visuais e, sobretudo, auditivas. Ela não se preocupa com os pés no chão, seja barro, assoalho encerado ou macio tapete. O ambiente lhe chega por outras vias. Como as torres da catedral c as copas do pinheiros, ela olha de cima, não por falta de modéstia, mas por preferir o que a vista abarca desse ângulo. Seus ouvidos ouvem a canção dos pássaros e as vozes e ruídos que anunciam produtos à venda. Em uma era pré-consumismo, os produtos ofertados atendem a necessidades básicas. Para quem vive do e para o comércio da escrita, o texto para ser lido, contendo o

6 VENTURELLI, Paulo (Org.). Helena Kolody. Curitiba: Editora da UFPR, 1995. p. 39. Série Paranaenses, n. 6. 
mundo transformado em letra - no caso, o jornal - é presença tão forte quanto a lenha e os alimentos que ela cozinha.

Se a poeta se recusa a dar atenção aos pés na lama, são os pés afundados na lama, ou melhor, as rodas no barro, em outro tempo e bem longe da rua Itupava, o motivo de um conto que apresenta uma cena típica do tempo da ocupação do norte do Estado. Em "O Encalhe dos Trezentos", Domingos Pellegrini Júnior, contista cuja tônica é a colonização daquela porção do Paraná e as peculiaridades da região, transforma em páginas antológicas uma experiência corriqueira naquelas condições.

O primeiro período cria a ambientação, secamente informativo, fornecendo dados temporais, geográficos, climáticos e viários precisos: "O Encalhe dos Trezentos começou às seis horas da manhã escura de 11 de agosto de 1958 , no atoleiro do quilômetro 60 da Cianorte-Cruzeiro do Oeste, a estrada mais perebenta do Brasil."7 O primeiro caminhão a encalhar, pesadão pelas próprias características e pela carga, é uma marca da época e do espaço: "Um FNM com carga de peroba [...]." Nos dois primeiros parágrafos, relativamente longos, funcionando como introdução, os olhos do narrador se detêm no experiente motorista, que desde o princípio sabe da impotência do ser humano diante da catástrofe que tem início. Serão sete longos dias. O tempo é a angústia maior de quem espera.

No "primeiro dia" - a ordenação dos dias dá título às partes - todos os esforços são empregados na tentativa de tirar o caminhão do atoleiro e liberar o tráfego, o que só faz piorar as condições da estrada e aumentar o número de veículos que não podem ir nem para frente nem para trás. Só alguns jipes conseguem manobrar e voltar sobre o próprio rastro, levando uma poucas mulheres e crianças. São "duzentos caminhões, sete ônibus e o restante miudezas de apenas quatro rodas" imobilizados, "cobra de lata colorida", no atoleiro "filho das sombras daquela mata". 8 Com trânsito livre entre tais imagens e o rude linguajar dos motoristas profissionais, o narrador compõe o seu discurso, descrevendo minuciosamente cada expediente, desde a caminhada das mulheres e crianças até Cianorte, escorregando na lama sob a chuva, no "segundo dia", até o "sétimo dia", quando, sob "o mormaço daquela manhã", os motoristas gritaram todos os palavrões que conheciam, palavrões que "acabaram engolindo" no "primeiro dia", e soltaram antes de tocar "cada um pro seu destino".

7 PELLEGRINI JÚNIOR, Doningos. O encalhe dos trezentos. In: O homem vermelho. Rio de Janeiro: Civilização Brasileira, 1977. p. II.

8 Id., p. 12-13.

9) $\quad l d$, , 2. 20-21. 
Mas o "Encalhe dos Trezentos" ficou, nome próprio, do lugar ou do conto, uma criação que levou bíblicos sete dias, as sete partes do conto.

Na década de 50, enquanto os habitantes do norte enfrentavam chuva e lama, seus vizinhos do sudoeste enfrentavam forças mais impiedosas e revoltantes, reeditando a luta do Contestado vivida por seus pais e avós. O desrespeito aos posseiros, da parte do governo, que paga dívidas com terras já ocupadas, é o assunto de Roberto Gomes em Os dias do demônio (1995). Singularmente, os moradores do lugar acabam impondo seus direitos. É o tipo de desfecho sobre o qual sc diria "só em livro", se não fosse factual. Mas até que se conquiste esse final, que não pode ser considerado tão feliz, pelas marcas que deixou, muito sangue correu, muitos sacrifícios foram impostos à população. $O$ romance delineia cuidadosamente as personagens envolvidas no conflito, de modo a representarem a classe, mas sem cair na estereotipia. São preservadas a individualidade e a originalidade da história de cada um, quase todos migrantes que vêm do Rio Grande do Sul e de Santa Catarina, a maioria refazendo, em escala menor, a saga dos antepassados, que vieram da Europa em busca d' "O paraíso", título da primeira parte, paraíso que pouco dura, porque "A guerra é sempre", vive-se "De ferro e fogo", atingindo-se "As portas do inferno", títulos da segunda, da terceira e da quarta partes, respectivamente.

Um dos grandes obstáculos de quem se propõe a escrever um romance histórico é acertar a mão na dosagem do discurso histórico, do sociológico, do antropológico, do psicológico, daí extraindo o ficcional. Como criar uma situação, que depende de muitas análises e explicações, sem que estas denunciem seu estatuto? Como dar vida a personagens que têm correspondentes empíricos, ainda mais quando o tempo da ação é relativamente recente? Como relatar linearmente, condição da escrita, palavra sucedendo a palavra, período a período, parágrafo a parágrafo, fatos concomitantes e interdependentes, ainda mais acontecendo em espaços diferentes, com o agravante de serem objeto de outros registros e, portanto, comportarem outras visões? Narrador experiente, Roberto Gomes não se deixa enredar nessas armadilhas. Ele empresta voz às personagens $\mathrm{em}$ falas curtas, de modo a não torná-las grandiloqüentes, penetralhes na consciência, entremeia pensamentos, sensações e descrição de ações, sem fratura entre o discurso do narrador e os discursos das personagens, as informações jogadas cá e lá, de modo a introduzir o leitor naquele universo, scduzido pela falsa naturalidade do romance bem elaborado. Não há heróis, mas homens que, sem possibilidade de escolha, são tranformados em mártires, preço da sobrevivência dos companheiros. Mesmo os que poderiam ser identificados como vilões - jagunços que, a serviço da companhia colonizadora, amedrontavam e perseguiam os colonos - não são títeres do mal, ganhando uma história de vida que lhes dá profundidade psicológica. O poder instituído, que se divide 
entre governantes e donos do capital, estes sustentando aqueles, é o grande culpado.

O litoral, porta de entrada da civilização branca, não deixa de marcar sua presença no discurso literário. Mar paraguayo (1992), de Wilson Bueno, coloca em cena as praias de Guaratuba, ou antes, uma velha marafona que aí vive, exercendo o métier de sortista e buscando a verdade sobre se terá de fato assassinado o amante, "el viejo". Este é o resumo e é o mesmo que não dizer nada sobre a novela.

Essa "canción marafa", ao mesmo tempo que, como experimento de linguagem, filia-se à linhagem de Mallarmé e Joyce, a personagem narradora se inscreve na galeria onde estão personagens como o do conto machadiano " $\mathrm{O}$ enfermeiro" e como Riobaldo de Guimarães Rosa, a experiência de vida transformando-se num relato questionador em busca da verdade, escrita com urgência "para que no se rompa dentro las cordas del corazón", como acentua Heloísa Buarque de Hollanda no texto de apresentação. ${ }^{10}$ Rompendo com os universos lingüísticos que o antecederam e instaurando uma nova língua, a voz narrativa transita livremente entre o português, o espanhol, o guarani, um ou outro galicismo e quem sabe o que mais. Não é a mera transposição para a escrita do portunhol que se ouve nas fronteiras e na voz dos latino-americanos de fala castelhana que migraram para o Brasil. É o próprio discurso transformado num "juego-de-jugar", desconcertante, compulsivo e convulsivo, a cada lance estabelecendo novas regras. $O$ resultado é que as fronteiras nacionais, lingüísticas e culturais entram num processo caótico. O cosmos que surge dai é Mar paraguayo.

O Paraná, particularmente Curitiba, salta dos contos de Dalton Trevisan com a força de verdade que só o imaginário tem. Da cidade, sempre a mesma e sempre outra, o olhar do artista seleciona aqueles ângulos que, antes da preocupação com o politicamente correto, denominavam-se "baixo mundo", bas-fond, a carga grosseira perdendo sua força, minimizada pela sonoridade da língua de cultura erudita por excelência. Mundo de personagens que o criador faz se defrontarem com a vida sem falsos pudores, sem meias-tintas, sem disfarces, sem atenção às conveniências sociais.

A coletânea Em busca de Curitiba perdida (1992) reúne uma série de textos que resume a geografia da contística de Dalton Trevisan. O conto que abre o volume e empresta seu título ao conjunto, anteriormente publicado no livro Mistérios de Curitiba (1968), deslocando na paródia o aspecto temporal

10 BUENO. Wilson. Mar paraguayo. São Paulo: Iluminuras/Curitiba: Secretaria do Estado da Cutura do Paraná, 1992. 1." orelha. 
dominante no original proustiano para o espacial, traz uma cidade bifronte: a Curitiba que o contista assume, amante e cúmplice, e a Curitiba que nega, enfastiado com a obediência às convenções.

Texto em primeira pessoa, opção que raramente freqüenta, o narrador transita entre as facetas da cidade que lhe interessam, constitutivas da própria matéria de seus contos, e as facetas que recusa, ainda que reconhecendo-lhes a existência. O conto gira em torno do verbo viajar, signo polivalente, que vai ganhando novos sentidos a partir de usos gramaticais e construções sintáticas inesperados: "Curitiba, que não tem pinheiros, esta Curitiba eu viajo. Curitiba, onde o céu azul não é azul, Curitiba que viajo. Não a Curitiba para inglês ver, Curitiba me viaja."

O discurso é o desenvolvimento destes períodos de abertura, particularizando e opondo os aspectos em que o autor viaja - a Curitiba das polacas vendendo ovos e galinhas, a dos "conquistadores de coco e bengalinha", do Gigi, dos bailes da Sociedade Operária, das meninas suburbanas, das ruas de barro, dos calfetões, dos bailes de várzea, das pensões de estudantes, da Ponte Preta, enfim, toda essa Curitiba que ganhou foros de cidadania estética na obra do contista - àqueles aspectos que nega - a da Academia Paranaense de Letras, do Museu Paranaense, "a do Emiliano, onde o pinheiro é uma taça de luz; de Alberto de Oliveira do céu azulíssimo; a de Romário Martins em que o índio caraíba puro bate a matraca [...]", enfim, essa Curitiba da tradição e do típico, construção validada pela chancela oficial. A separação entre o aceitável e o recusável não é temporal nem topográfica, mas institucional.

No último parágrafo Curitiba se personifica, tratada por "vosmecê", próxima, íntima - "província, cárcere, lar" - aspecto triádico que se reflete na repelição do verbo central, fechando o conto: "com amor eu viajo, viajo, viajo".

Paulo Leminski, o poeta de Curitiba como Dalton é o contista, ainda que tão díspares entre si, também recorre ao uso inusitado do pronome reflexivo, fazendo com que o "nascer paranaense", em posição central, torne-se o foco nos versos do poema sem título:

Transar bem todas as ondas

a Papai do Céu pertence,

fazer nascer as luas redondas

ou me nascer paranaense.

A nós, gente, só foi dada

essa maldita capacidade,

tranformar amor em nada. ${ }^{12}$

11 TREVISAN, Dalton. Em busca de Curitiba perdida. In: Em busca de Curitiba perdida. Rio de Janeiro: Record, 1992. p. 7-9.

12 LEMINSKI, Paulo. Distraidos venceremos. São Paulo: Brasiliense, 1987. p. 24 
Também são muitas as curitibas que constituem o tema de "Imprecisa premissa", o tom de ladainha conduzindo à origem da cidade, até confundi-la com a santa contida no seu antigo nome, rogando piedade, não à protetora celestial, mas à cidade:

\title{
IMPRECISA PREMISSA
}

(Quantas curitibas cabem numa só Curitiba?)

\author{
Cidades pequenas, \\ como dói esse silêncio, \\ cantilenas, ladainhas, \\ tudo aquilo que nem penso, \\ esse excesso \\ que me faz ver todo o senso, \\ imprecisa premissa, \\ definitiva preguiça \\ com que sobe, indeciso, \\ o mais ou menos do incenso. \\ Vila de Nossa Senhora \\ da Luz dos Pinhais, \\ tende piedade de nós. ${ }^{13}$
}

A curitibanidade manifesta-se em outros poetas como recusa de abandonar a cidade, ainda que seja preciso reinventá-la pelo experimentalismo, abolindo pontuação, deslocando os versos no branco da página e empurrando o título para a última linha, como faz João Gilberto Tatára:

\author{
tanto fiz \\ que o tempo refez a ferida \\ molhar n'água salgada do tempo \\ as retinas \\ de olhar a saudade \\ esgarçar na torre da Catedral \\ teu nome \\ continuar morando em Curitiba
}

CARTÃO POSTAL ${ }^{14}$

13 LEMINSKI, op. cit., p. 59

14 Sangra: Cio. [Curitiba, Edição dos Autores], 1980. 
Curitiba, para Cristovão Tezza, não é uma fonte de angústia, de sentimentos contraditórios, mas a garantia de pés bem plantados no chão, de cenário em que move suas personagens com segurança, disponíveis para viverem seus dramas. Espaço da maioria dos romances do ficcionista que elegeu Curitiba também para viver, Uma noite em Curitiba (1995) é o mais curitibano desde o título.

A história narrada tem como protagonista Frederico Rennon, 50 anos, renomado professor de história da Universidade Federal do Paraná. Em 1993, o professor organizou um "Ciclo de Palestras e Debates sobre o tema Literatura e Cinema no Brasil", ocasião em que uma atriz convidada lhe traz de volta seu passado, passado de engajamento político - no ano de 1968 o jovem Rennon, numa passeata, matara um homem que registrava as cenas com uma câmara - $\mathrm{e}$ de envolvimento com a atriz, naquele tempo uma militante que o convence do perigo que corre e da necessidade de fugir. Esse envolvimento, 25 anos depois, no reencontro propiciado pelo Ciclo, transforma-se em paixão violenta.

O leitor conhece o enredo pelo relato de dois narradores-personagens, únicas vozes em todo o romance. Quem se apresenta já na primeira linha é o filho do professor - "Escrevo este livro por dinheiro"-, sinceridade tão reiterada que logo parece suspeita. Os períodos seguintes dão a entender que a história já chegou ao seu desfecho, e o filho, que se apresenta como pretenso poeta e jovem desajustado, se tem aquela intenção confessa, no fundo, o que quer é entender o pai, com quem sempre tivera uma relação problemática. Organizador do texto, ele recorre com frequêencia à colagem dos arquivos encontrados no computador do pai - correspondência oficial, anotações profissionais e cartas íntimas que, no final, tomam a feição de um diário pessoal. Assim, simulando algum desajeitamento narrativo, uma certa falta de confiança no seu discurso, mantém o suspense sobre dois pontos. Até cerca do final do segundo terço do texto, o leitor se pergunta sobre o que aconteceu com o professor entre o final do evento acadêmico e o momento da escrita do livro, mas quer antes entender por que o professor viera para Curitiba, qual a culpa que expiava, qual era o crime, sempre evocado sem detalhes. Depois do relato-rememoração do assassinato, integralmente colado de uma carta, entendendo-se por que Rennon só podia șer professor de história e ainda dedicar-se à pesquisa sobre a trajetória de uma geração, agudiza-se a certeza de que há outro mistério. Sabe-se que o professor já não está no espaço familiar nem no acadêmico. A decisão do professor de abandonar família e trabalho para seguir a atriz já tem algum impacto, mas o desfecho não perde a força. A morte fora anunciada nas entrelinhas. Ainda assim, o suicídio espetacular pega o leitor desprevenido.

A flutuação de narradores, além de denunciar a relativização do relato de cada um, mostra dois mundos, ambos contidos no mesmo espaço topográfico, 
cujo centro é o Teatro da Reitoria da UFPR, tendo como limites percorridos a pé o Jardim Social e a Praça Osório, com hotel, teatro, bares e cinemas ao longo do percurso. Os trajetos feitos de carro também são precisos e corriqueiros: almoço em Santa Felicidade, jantar no Tortuga, ida ao aeroporto, além da decisiva fuga a um motel na estrada de Paranaguá. A maioria dos figurantes desse cenário é constituída, além da família, pelo universo acadêmico, visto pelo óculo irônico do jovem, inclemente no desnudamento da classe. A inclusão no enredo do evento de caráter nacional é decisiva porque é a diferenciação de atitudes entre os "de fora" e os "da casa" que dá oportunidade para o destaque dos comportamentos característicos destes. Nesse sentido, o par professor e atriz é modelar. Nada mais apropriado para delatar o convencionalismo do professor que a contraposição ao descompromisso e à irreverência da atriz. Sob o efeito de seu amor, o olhar do professor realiza uma tranformação plástica em Curitiba: "[...] fui transformando o cinza e o azul bem-comportados de Curitiba em amarelos e vermelhos de Van Gogh. [...] Como se eu entrasse fisicamente nas curvas e nas texturas do óleo, pinceladas de Van Gogh, curvas de Gauguin, os volumes de Cèzanne. A cidade inteira colorida, e eu vagando no meio das plantas vivas de tinta." 15

Caleidoscópica é a Curitiba criada por Jamil Snege em Como eu se fiz por si mesimo (1994). Estes são tempos gloriosos para o memorialismo, não mais proscrito dos limites do estético, mesmo porque não se distinguem mais limites, além de continuar reconhecido pelos antigos predicados: testemunho de época, exemplaridade da experiência pessoal, registro de fatos que poderão transformar-se em história.

A cidade, que o senso comum acredita pacata, provinciana e bem comportada, tem o seu memorialista, que é não só o oposto do meio, como contraditório em relação a si mesmo: cosmopolita e suburbano, sarcástico e terno, indivíduo liberto de todas as amarras com os méritos burgueses e profissional cujo sucesso depende de saber tirar partido do consumismo.

Memorialista? Ou cronista? Quem sabe romancista? Às vezes poeta? Talvez contista? Provavelmente tudo isso junto, mas o resultado não é a simples soma das partes, nem é passível de divisão. O leitor apressado pode considerar que essa personagem de "si mesmo" - o título pode não ser lido apenas no sentido de "fazer-se na vida", mas também de fazer a si mesmo personagem de um tex to - confessa, com igual cinismo, tanto seus pecados como os dos outros, inclusive seus amigos. Mas as palavras cinismo, confessa e pecados não pertencem ao campo semântico a freqüentar quando se avalia o discurso de Snege, que não faz um mea culpa e tampouco um exercício de "dedodurismo". Ele narra o ser humano que existe nele e nos outros. Classificá-lo como um contestador é

15 TEZZA, Cristovão. Uma noite em Caritiba. Rio de Janeiro: Rocco, 1995. p. 97. 
pouco, ou não é verdadeiro. Quem contesta propõe, conscientemente ou não, outra escala de valores. Antes talvez convenha chamá-lo desencantado. Não é à toa que ecos machadianos ressoam cá e lá na sua escritura.

Não se tentou traçar aqui o esboço da história da literatura no Paraná, nem se buscou investigar se existe uma literatura paranaense. Reiteradamente, a propósitos diversos, observou-se que já não há lugar e não é tempo de se procurar encontrar ou estabelecer fronteiras fixas. Os contornos são sempre móveis e fluídos. Se é necessário classificar esta abordagem, pode-se dizer que ela se fez com uma orientação localista, não porque esse seja um critério estético, mas em vista de um interesse específico: flagrar imagens do Paraná - geográficas, históricas, sociais - na figuração literária. Provavelmente passou-se à margem deste ou daquele texto que pode ser lido como a essência do ser paranaense, se acreditarmos que essa essência existe. Este "passeio pelos bosques" do discurso literário que presentifica o Paraná nem sempre seguiu a trilha principal, ou nem mesmo ela foi percebida como tal. A caminhada foi em ziguezague, sem roteiro prévio inflexível, por vezes sofrendo guinadas, em busca de uma cor indefinida, um movimento apenas pressentido, um ruído quase inaudível, o vislumbre de uma clareira. Por mais que o texto crítico tente significar, a experiência estética é intransferível. Cabe a cada um e a cada momento a escolha da senda. É essa virtualidade da literatura que faz o encantamento e o desespero do leitor.

\section{RESUMO}

Tentativa de flagrar imagens do Paraná - geográficas, históricas, sociais - no discurso literário. sentação.

Palavras-chave: literatura paranaense, o Paraná na literatura, espaço e repre-

\section{RÉSUMÉ}

Ce texte essaye d'apréhender quelques images géographiques, historiques e sociales de l'état du Paraná dans le discours littéraire.

Mots-clé: littérature du Paraná, Paraná dans la littérature, l'espace et représentation. 


\section{REFERÊNCIAS BIBLIOGRÁFICAS}

BUENO, Wilson. Mar paragıayo. São Paulo: Iluminuras/Curitiba: Secretaria do Estado da Cultura do Paraná, 1992.

COELHO, Salvador José Correia. Passeio à minha terra. São Paulo: Typografia da Lei, 1860. Edição em fac-símile, 1968.

GOMES, Roberto. Os dias do demônio. Porto Alegre: Mercado Aberto/São Carlos: Editora da UFSCar, 1995.

KOLODY, Helena. Correnteza. Curitiba: Lítero-Técnica, 1977.

LEMINSKI, Paulo. Distraidos venceremos. São Paulo: Brasiliense, 1987.

MENEZES, Emílio de. Obra reunida. Rio de Janeiro: J. Olympio/Curitiba: Secretaria da Cultura e do Esporte do Estado do Paraná, 1980.

NASCIMENTO, Noel. Casa verde. São Paulo: Martins, 1963.

PALLIUM. Curitiba, 1898 e 1900. Edição fac-similar, Curitiba: Secretaria de Estado da Cultura e do Esporte, 1982.

PELLEGRINI JÚNIOR, Domingos. O homem vermelho. Rio de Janeiro: Civilização Brasileira, 1977.

REVISTA DA ANTROPOFAGIA. São Paulo, 1928-1929. Ediçāo fac-similar, São Paulo: Metal Leve, 1975.

SANGRA: CIO. [Curitiba: Edição dos Autores], 1980.

SILVEIRA, Tasso da. Sombras no caos. [Rio de Janeiro]: GRD Edições, [1958].

SNEGE, Jamil. Como eu se fiz por si mesmo. Curitiba: Travessa dos Editores, 1994.

TEZZA, Cristovão. Uma noite em Curitiba. Rio de Janeiro: Rocco, 1995.

TREVISAN, Dalton. Em busca de Curitiba perdida. Rio de Janeiro: Record, 1992.

VENTURELLI, Paulo (Org.). Helena Kolody. Curitiba: Editora da UFPR, 1995. Série Paranienses, n. 6.

XAVIER, Valêncio. O mez da grippe. Curitiba: Fundação Cultural/Casa Romário Martins, 1981. 